DOI: 10.15642/JIIS.2016.10.2.159-180

\title{
SOEHARTO AND THE POLITICIZATION OF INDONESIAN ISLAM (1968-1998)
}

\author{
Masykur Hakim \\ UIN Syarif Hidayatullah, Jakarta - Indonesia | masykurhakim@yahoo.com
}

\begin{abstract}
Soeharto treated Indonesian Muslim Communities with two different ways. On the one side, he has given them full freedom to conduct Islamic rituals such as prayers, almsgivings, fasting during Ramadhan, pilgrim and so on. On the other side, however, he has not given them full freedom to exercise politics at the practical level because it would raise problems in the long run. He handled their political activities tightly. Therefore he put whatever efforts necessary to safeguard his power interests such as launching Pancasila as the sole basis (asas tunggal) for all political parties and mass organizations, merging four Islamic political parties into one party, PPP and so on. After more than 30 years he conducted the politicization of Islam, the big mutiny and turbulences happened everywhere which was supported by all university students and caused the fall of his power in 1998 with sad ending and Indonesian reform era started.
\end{abstract}

Keywords: Soeharto, Indonesian Islam, New Order, politics.

\section{Introduction}

In the history of Indonesian politics, Christian Snouck Hurgronje, Soekarno and Soeharto have applied Ali Abdul Raziq's notion of secularism. Even in the New Order regime, President Soeharto handled Islamic affairs in the country based on the separation between religion and politics. The main reason of the two former Indonesian Presidents taking the decision was experience of the politics apparently 
weakened, the role of its religious and social dimensions has developed and flourished from time to time until today. ${ }^{1}$

The Indonesian development has shown a paradoxical implementtation of models of the development between liberal model of Talcott Parsons and conservative model of Huntington. In the Parsons Paradigm, development means the change of social and economic structure and shift from a traditional system to a modern one that may result in social mobilization, development, while in the Huntington paradigm, development becomes a combination of modernity and tradition with an effective government. ${ }^{2}$

The first paradox is that national development in Indonesia has, to some extent, adopted elements of a liberal development by the creation of modern forms of social and economic structures, yet in the meantime reviving classical indigenous traditions. The second paradox lay in the fact of economic liberalisation at the cost of strong political control.

Strong evidence of that kind of development is to be found in the two different directions of structural transformation that occurred in the economic field and the political one respectively. Structural transformation in the economy has already seen a shift of the income of society from agriculture sector in the agro industry, industry in profit sectors.

The change of civic polities, on the other hand, indicated structural transformation in polity by praetorians. According to Huntington, the civic polity is a type of politics in which one or more independent political forces dominate social spheres, whereas praetorian power of a government is that which is not controlled by the political parties. ${ }^{3}$ The latter term might not fit in to Indonesian politics very well, but some elements of praetorianism were discernible in the New Order government, such as the absence of an independent effective political force, the strength of bureaucracy in decision-making process, and its expansion and interference into almost all social spheres.

1 Victor Tanja, HMI: Sejarah dan Kedudukannya di Tengah-tengah Gerakan Muslim Pembaharu di Indonesia (Jakarta: Pustaka Sinar Harapan, 1982), p. 142.

2 See Samuel P. Huntington, Political Order in Changing Societies (New Haven and London: n.p., 1968), pp. 80-83.

${ }^{3}$ R. William Liddle, "Soeharto's Indonesia, Personal Rule and Political Institution," in Pacific Affairs, No. 58 (1985): pp. 68-90. 
In relation to the "ideology" of development, a praetorianistic polity has, of course, a political logic of its own, such as an argument for the necessity of national stability for the success and sustainability of development itself. The accentuation of national stability has been the characteristics of the New Order's political engineering. Political institutionalization in this respect is reflected in the security and monolithic approaches exercised by the New Order government. As a consequence, the degree of political participation has been weakened, particularly because political parties, as vehicles of political expression, were not able to articulate the political interest of the people.

The political institutionalization achieved thus has not encouraged people's political participation, because the institutionalization process only strengthened what Liddle has called the "New Order Pyramid". 4 This pyramid consists of a dominant presidency, which becomes the centre of decision-making, and pattern of state society relationship that combines co-option and response with repression.

According to Liddle, the mechanism of the New Order political structure departs from the presidency at the top, giving commands to the military which is the most important element of the bureaucracy and, in turn, exercises power over society. The whole process of political engineering has effectively created a relatively stable condition of the relationship between state and society, or between the ruler and the ruled.

It is in such a political setting that the de-politicization of Islam has been processed. The manner of the process took the form of getting rid Islamic symbols for political activities, eliminating Islamic political parties, and clearing the political arena of Muslim politicians. The depoliticization of Islam has reached its culmination in terms of political vehicle in the amalgamation of all existing Islamic political parties into United Development Party (Partai Persatuan Pembangunan/PPP) in 1973, and in terms of political ideology in the obligation to adopt Pancasila as the asas tunggal (the sole basis) by all political parties and mass organizations in 1985.

The de-politicization of Islam was part of a broader scheme, namely the de-politicization of the people in general. This was seen in the creation of a floating mass population which de-politicized people at the grass-roots level and alienated political leaders from their

\footnotetext{
${ }^{4}$ Nasir Tamara, "Islam under the New Order: A Political History," in Prisma (English Edition), No. 49, (June 1990), p. 14.
} 
followers. The streamlining of political parties followed this in to Golongan Karya (Golkar), the PPP, and the Partai Demokrasi Indonesia (PDI). Islamic political parties responded in a relatively "easy" way toward this streamlining, though the story behind the creation of the PPP is not simple, as Nasir Tamara maintains. ${ }^{5}$

From the beginning, NU was the largest member among Muslimbased political parties. Although initially not very keen on merging, $\mathrm{NU}$ eventually joined into the fusion without internal conflict. On the other hand, there was unrest within Partai Syarikat Islam Indonesia (PSII) resulting in a leadership change, which was won by pro-merger people. On the other hand, Partai Muslimin Indonesia (Parmusi) and Persatuan Tarbiyah Islamiyah (Perti) supported a quick merger from the start. 6 This "easy and quick response" was due in part to the situational logic of politics at that time that led political parties to follow the current of political engineering, and in part to an "intrinsic competition" among Islamic political groups to be seen as the first supporter of the regime.

Escaping from the obligation not to include any mention of Islam in the new party's name, Muslim leaders have chosen the terms persatuan (unity) and pembangunan (development). They hoped by so doing not to delete some mention of Islam, because the term persatuan indicates one of the most important principles of Islam. They also hoped that the amalgamation would provide them with Hikmah (blessings in disguise) and to establish ukbuwah Islamiyah (Islamic brotherhood). The adoption of the term pembangunan was perceived as agreement with and support for the New Order's policy of development. It is possible that the use of the terms persatuan and pembangunan was meant to convey a message that the PPP, the "Islamic" party, had emerged to gain the support from the Muslim community in order to participate in the national development process.

It is notable that Muslims' responses to the political change during the first ten years of the New Order (1996-1976) which, in relation to the agenda for the de-politicization of Islam, might be identified as a "period of conditioning" that appeared more political in nature, although with critical accommodation. Little intellectual response was shown, such as elaboration on the relationship between Islam and the

5 Ibid., p. 15.

${ }^{6}$ Muhammad Kamal Hassan, Muslim Intellectual Responses to "New Order" Modernization in Indonesia (Kuala Lumpur: Dewan Bahasa dan Pustaka, 1980), p. 78-116. 
state, the Pancasila, and politics with the exception of the accommodationist responses of Mintaredja and Nurcholish Madjid. ${ }^{7}$

Mintaredja (the-then chairman of Parmusi and later President of the PPP) in his reflection on Islam and the Pancasila considered that Islam does not aim at the creation of an Islamic state because during the time of Prophet Muhammad, the term "state" in today's sense of the state was not yet in existence. ${ }^{8}$ In the Mintaredja's view, the major duty of Muslims is to struggle for creating a true Muslim society which should be distinguished from an Islamic state. A Muslim society could legitimately exist in a state without undermining its integrity as the nation-state. ${ }^{9}$ Concerning the relationship between Islam and politics, Mintaredja believed in the totalistic character of Islam as a way of life, including political life. He maintained that politics is worldly in nature and an approach to political issues should be in accordance with its nature.

Similar to Mintaredja's idea as mentioned above, Nurcholish Madjid has promoted a slogan popularly on the eve of the 1970's as "Islam-Yes, Islamic party-No". This slogan lately became one of the main points of this "his renewal project" which was severely criticised and resisted by many Muslims. ${ }^{10}$ Having observed the problems of Indonesia Islam, which lay in the paradox between the defeat of politicised Islam and its rapid expansion, Nurcholish Madjid came to the conclusion that Islam's quantitative growth was not encouraged by the Islamic parties or Islam organizations, for the Islamic parties had failed to build a positive and sympathetic image of Islam. ${ }^{11}$

According to Munawir Sjadzali, in certain circumstances, the absence of the Islamic political parties was better for Muslims. The experiences of national life in the past few years clearly showed that the interests of Muslim ummah were even well taken care of when there was no Muslim party in the Indonesian political sphere, he said. ${ }^{12}$

\footnotetext{
${ }^{7}$ H. M. S. Mintaredja, Renungan Pembaharuan Pemikiran: Masyarakat Islam dan Politik di Indonesia (Jakarta: Permata, 1971), p. 77.

8 Ibid., p. 78.

${ }^{9}$ For more detailed in this account, see Nurcholish Madjid, "Keharusan Pembaharuan Pemikiran Islam dan Masalah Integrasi Ummat," in Nurcholish Madjid, et al., Pembaharuan Pemikiran Islam (Jakarta: Islamic Research Centre, 1970), pp. 1-12.

10 Ibid.

${ }^{11} \mathrm{H}$. Munawir Sjadzali, Muslim's Interests are Better Served in The Absence of Muslim Parties, Indonesia Experience (Jakarta: Ministry of Religious Affairs, 1992), p. 2.

12 Ibid., p. 3.
} 
From the start of the New Order, especially in the last decade, many expectations of Muslim for the improvement of religious infrastructure and facilities have been sufficiently met. In the past, at the time when Muslim parties were present, the same expectations had never been fulfilled. The following examples could be advanced.

In the field of law, for instance, with the passing of law Number 14 of 1970 on judicial Authority, the existence of the Law of Religious Court (Islamic Court) is fully recognized as an independent law court and equal to the other three Courts of law: Public Court, Administrative Court, and Military Court. This law was then followed by the enactment of law No. 7 of 1989 on Religious Court, some of which had prevailed for more than 100 years, and at the same time served as the realization of the stipulation contained in law No. 14 of 1970 on the independence of the Religious Court, to the other three laws. ${ }^{13}$

In this context, it should be noted that in 1948, a Muslim party brought up a proposal for the improvement of religious court status to KNIP (Komite Nasional Indonesia Pusat, or the Indonesian National Central Committee) which, at that time, served as provisional parliament, but the proposal met with strong opposition from other parties or factions and, being a minority group at the time, the party could do nothing about it. ${ }^{14}$

In regards to the development of law, up to the year 1991, religious judges had no standardized books of law similar to the KUHP (Kitab Undang-Undang Hukum Pidana, or the Penal Code) for judges in the Public Court, even though the Religious Court had been established long before; the religious judges had to resort to numerous yet diverse reference of figh books in dealing with the legal issues brought up by members of the community. As a result, it often happened that they were two similar cases, headed by two different judges with two different books of reference, would result in two different verdicts, which meant that there was no legal certainty.

The peculiar situation ended, once again, at the time of the New Order, in the absence of Muslim parties, with the issuance of a jointdecree of the President of the Supreme Court and the Minister of Religious Affairs on the establishment of an Islamic Law Compilation

\footnotetext{
13 Madjid, "Keharusan Pembaruan Pemikiran Islam, p. 15.

${ }^{14}$ Robert W. Hefner, "Islam, State, and Civil Society: ICMI and the Strategy for the Indonesia Middle Class," Indonesia, October (1993), p. 11.
} 
Project (Kompilasi Hukum Islam/KHI). In December 1987, the project succeeded in completing three draft books as legal references to be used by the religious judges throughout Indonesia. The first book is on marriage, the second one is about the law of inheritance, and the third one on waqf (religious endowment). By the presidential instruction No. 1 of 1991, issued on June 10, 1991 just one week before the President and his family made a pilgrim to Makkah, those three books were officially put into effect and ordered to be publicly used. ${ }^{15}$

In the field of education, Indonesia has the law Number 2 of 1989 on National Education System, in which religious education is affirmed as a sub-system to the National Education System, and religious instruction is compulsory at all public schools and universities. The law also reaffirmed recognition to the long existing religious education institutions in conformity with the claim of the New Order that the state which, is based on Pancasila is neither a theocratic nor a secular state.

In the relation to houses of worship there has been a sharp increase in the number of mosques and mushalla including over 500 strong and beautiful mosques built by the Yayasan Amal Bhakti Muslim Pancasila (Muslim Charity Foundation) Chaired by President Soeharto. ${ }^{16}$

In the realm of dakwah (Islamic propagation), it is well known that the major weakness of socio-Islamic organizations is a serious lack of financial back up. An international Islamic organization once promised to help the financing of 1000 preachers for the whole country. However, the realization was only for 300 preachers, far below the target, and later the number went down to just a little more than $100 .{ }^{17}$ To cope with that unfavourable situation and being fully aware of the urgency for religious guidance in the remote and isolated areas especially in the transmigration locations President Soeharto urged the MUI (Majelis Ulama Indonesia, or The Indonesian Council of Ulama) to prepare 1000 da'i (preachers) for religious duties in transmigration sites. They would receive Rp. 100.000 per month for the period of three years as financial support from the Yayasan Amal Bhakti Muslim Pancasila. The same foundation has also donated financial support for

\footnotetext{
15 Ibid., p. 15.

${ }^{16}$ Ibid., p. 11.

17 Ibid.
} 
other 1000 imams for transmigration sites channelled through the MDI (Majelis Dakwah Islamiyah, or The Council for Islamic Preaching). ${ }^{18}$

During the Old Order regime under President Soekarno and still more so under the Soeharto's New Order regime, the Indonesian government was directly or indirectly involved in the construction of many mosques and the development of public institutions of Islamic religious education, from the primary school to the higher education such as IAIN (Institut Agama Islam Negeri, or The State Institute for Islamic Studies). ${ }^{19}$ The New Order regime, on other hand, has started for the de-politicization of Islam which was primarily materialized by the ban on political parties based exclusively on Islam or its particularities; it favoured the development of Islamic values in the social, cultural and intellectual spheres of life, in order to create the socalled "ethical" basis of national development.

Up to present time, Islam often functions as a source of motivation for demands of adjustment of different aspects of government policy. In the demands, the Islamic motive is generally combined with other reasons and motives, of a cultural, social, economic or political motif. An example is the movement for the democratization of the political system which has been growing for some years now. Its background is partly based on Islamic values, legal notions and organization.

The Islamic element was still more prominent in the recent campaign for the abolition of the SDSB (Sumbangan Dermawan Sosial Berhadiah, or social philanthropically Contribution with Prizes) lottery, in which formal arguments about Islamic law were combined with the denunciation of growing social and economic disparities. The latter campaign finally attained its goal on November 25, 1993, when the Minister of Social Affairs announced the discontinuation of the lottery. ${ }^{20}$ However, at present Islam is seldom a source of criticism of the political system or the public authorities as a whole in the country.

The democratic tradition that can accord respect to diversity was tough at practical level. The politics of concentration of power and the policy of incorporation in operation since long should be reviewed.

\footnotetext{
18 Ibid., p. 18.

19 Graha Insan Cita, Pidato Ketua Umum PB HMI pada Dies Natalis ke 51 (Depok February 5, 1998), p. 7.

${ }^{20}$ Ibid., p. 8.
} 
Indeed, the politics of concentration is not only irrelevant to the democratic tradition, but is also contrary to the heterogeneous social nature of the Indonesian people. The motto Bbinneka Tunggal Ika or Unity in Diversity is a cultural treasure of the Indonesian people which is quite relevant to be practiced in real practical life. The selection of public service officials should have represented and respected this pluralistic society.

The strong demand for democracy and healthy political activity has forced the government to review political life, together with the legislative institutions to review the rules of political game. From time to time the people's awareness towards their rights as citizens has increased, including right to politics and implementation of the clean government by the New Order administration.

In the last years of Soeharto administration, the political dynamics in the country has increased. After short period of decline following the repression of the Megawati supporters on 27 July 1996, a surge of democratic waves appeared throughout the archipelago. ${ }^{21}$ Reminiscent of the last days of Soekarno, the current democracy movements have been championed by the university students who launched their protest in response to the government which was seen as being incapable of controlling the crisis and its negative impacts on the life of the people.

The politics of de-politicization of Soeharto consists of two strategies; direct and indirect one. The first has targeted to the rural masses, which constitute bulk of Indonesian population (approximately 70 percent). It has taken the form of the so-called "floating mass" policy, the purpose of which is to limit the activities of political parties as far as the district level. The underlying assumption of the particular policy is to protect people from political manipulation by competing parties, which had occurred in the past and engendered political instability and promoted social disturbance.

The second strategy, namely the indirect strategy of depoliticization has been implemented through various mechanisms, most important of which were the state's corporatization, co-optation, and ideological hegemony. Through the corporatist mechanism, the state is able to put forth systematic control and surveillance over the

${ }^{21}$ HM Yusuf (ed.), 50 Tabun HMI Mengabdi Republik (Jakarta: LASPI, 1977), p. 132. 
existing interest groups in society through direct intervention in their existing organizations.

According to the Lt. General (ret.) Rudini, ${ }^{22}$ the rise of the people's political awareness should be accompanied also with the rise of the government's role and socio-political structure. It was quite important in order to meet the development demands, their aspirations and aggregation of people's political interest could be developed to become "affirmation potential" for sustained national development, not just "trouble-maker potential" which hampers national integration. Accordingly, the role of ABRI, political parties, Golkar and all the existing mass organizations, including youth organizations, should be enhanced maximally so that they could participate to increase the national awareness and to boost national unity in order to realize the national ideals based on Pancasila and the 1945 Constitution.

As custodians of people's aspirations all political parties and Golkar were expected to participate actively in enhancing the quality of development and democracy. In this context, the role of political institutions should be maximized. All socio-political forces in the country should work to prepare the people qualified for development and capable of channelling the socio-political aspirations of the grassroots; they are expected to serve the interest of the society, the nation and the state properly and consistently. Unfortunately, these political parties, particularly the Golkar as ruling party was regarded as a political vehicle by its leaders for their self-interest, their families and their cronies.

The role of mass organizations as medium to articulate the people's interest should be advocated and supported continuously. The rise of all social institutions, including youth organizations is quite helpful to enhance the quality of political awareness in support of national unity and integration for better civilized Indonesian people in the future. ${ }^{23}$ Due to secular education which was neutral towards religions, they became alienated from Islam. They tended to ignore the Islamic doctrine and the Shari'ah (Islamic Law). More than that, the secular educational system created friction among the Muslim youth between those who ignored and those who obeyed the Islamic doctrine. Above all, because in Java island could be found the tendency

22 Ibid., pp. 132-133.

23 A Komaruddin and M Fauzie, HMI Menjawab Tantangan Zaman Jakarta: KAHMI, 1990), p. 136. 
of religious assimilation, their presence in the secular education affected to deeper friction between the "heterodox" Muslim group and those who aspired to purify the Shari'ah (Islamic Law) from all kind of derivations.

In order to overcome the above problems, Deliar Noer has come up with an idea to develop nationalism based on the deepest religious heritage. Noer believes that a nation which has identied itself with the religion of its majority population is a basic key for national unity and integration. Therefore, the Indonesian strength lays in its identification with Islam, and only Muslim which hardly endeavoured to develop the Islamic basis of nation potential become "the ulama-intellectual and the intellectual-ulama“. 24

The above formulation placed the enhancement of faith and devotion to the one only God as the top priority in the national education objective. It was indicated that religious education in secular higher education should get the man concern, the fact of the seriousness is the ongoing perfection of the Islamic religious subjects in the secular higher education.

After long time the religious subject was given in the conventional way, and today in the secular universities, the Islamic concept of any discipline (IDI) was already taught. This indication is one step ahead with relating the process of science and technology to Islamisation. Besides, it has developed many ways to delve deeply into Islamic doctrine in various fields like economics, politics, culture, etc.

One the other side, the New Order administration policies generally weakened all Islamic university student organizations. Since its establishment, the New Order government engaged in bringing about economic development and repressing all political opponents and mass and religious organizations. This phenomenon is not peculiar to neo-fascists, not only in Indonesia, but it was also common to several third world countries like Brazil, Argentina and Iran under Syah Reza Pahlevi. ${ }^{25}$

Meanwhile, there is also a group who entered the system. This group called institutionalist, which struggled from within the structure. Some of them succeeded in supporting the processes of change from

\footnotetext{
24 Ibid.

25 Adi Sasono is ex-activist of Bandung branch HMI. Since May 1998 President B. J. Habibie appointed him as minister economic, co-operative and weak entrepreneurship development.
} 
within the structure. However there was a group disinclined to motivating the change process from within. Beside that, there was professionalist group which was neutral towards the political system. They tended to work related to the justice aspect, even distribution and freedom. They have given contribution, but their activities have not influenced to the wider community. They worked sectorally in their own field.

Therefore, a novel idea was needed to resume their activities and responsibilities based on professionalism. They did not need to do dichotomy between those worked in the state institutions and outside of it. But, they should develop togetherness in order to realize the sovereignty of the nation effectively. They needed to focus on the mass approach and practical action and more attention to the professionalism in their own field. It was a development of political education agenda. ${ }^{26}$

Democracy is a social process and also a learning one. The social control towards the decision-making which was quite often not inclined to justice was also time-consuming. To implement democracy shortcuts and romantic measures are not enough. The idea of revolution which is quite often talked in certain circle, particularly the radical young generation, did not offer the way-out of the ummab problems, because the problems were very complicated and needed to discern the importance of all socials forces to operationalize collective awareness.

In this connection, it could be seen the role off intellectual organizations like KAHMI, ICMI or the other, to develop a positive interaction, in order to struggle for justice and even distribution which did not end with lip-service. Slogan and philanthropy programmes inclined to defend status-quo. Theoretically, there is no difference between philanthropy programmes and even distribution one. The gift of philanthropy programmes is to provide a social agenda, but it did not have impact on concrete economic structure. What has been expected by the society is even distribution programmes and has the impact on the productive asset of entrepreneurship. ${ }^{27}$

The lessons were: First, the innate strength of economic globalization. The foreign debt should be utilized for the maximum benefit of people and their prosperity. Second, a tiny group of society

${ }^{26}$ Komaruddin and Fauzie, HMI Menjawab Tantangan Zaman, p. 154.

${ }^{27}$ Ibid., p. 157. 
could not develop the strength of economic foundation. The strength of the tiny group caused the collapse of national economy and disrupt its distribution.

At the practical level, the above constructive suggestions were not implemented by the government so that the apprehensions appeared and raised a huge social unrest and deep economic crisis in the country. The deepening economic crisis was accompanied by a growing political crisis Soeharto was facing from the people who had slowly and painfully begun to recover from the terrible defeat of 1965. The first major sign of the revival of resistance came in 1974 when a million people spilled onto the streets during widespread student protests. Yet they were also brought together as workers, and as "the 1980s progressed they began to use their collective strength to strike for better wages and working conditions with some success." 28

By 1996 the dissatisfaction against the Soeharto regime was spreading up to sections of the ruling and middle classes, who were being excluded from the profit and corruption bonanza by Soeharto's cronies. Protests at various levels were mounting throughout the country.

In the beginning of 1960's, some of Santri alumni entered universities and colleges. Seven years later, the booming of educated scholars from the Santri cultural background came into existence. After graduation, they became bureaucrats. Along with their career, for few years, they hid their Islamic identity and after they occupied an important position, they begun to "Islamize" offices, departments, or campuses. The managers and leaders of the office held pengajian or teaching of Islamic doctrines and performed congregation prayers in the place where they worked. In this context, lecturers revived the religious activities in their campuses. ${ }^{29}$

In order to resolve the deadlock, they constituted the Persami (The Indonesian Muslim Scholar Union) in 1964. While the New Order came into being, some of Muslim scholars headed by Subchan, Z.E, from NU element withdrew from the Persami, and established ISII (Ikatan Sarjana Islam Indonesia, or Indonesian Muslim Scholar association) affiliated to the NU party. Unfortunately the two Muslim

\footnotetext{
28 See footnote No. 41.

29 Jalaluddin Rakhmat, Islam Aktual, Refleksi-Sosial Seorang Cendekiawan Muslim (Bandung: Mizan, 1996), p. 101.
} 
scholars associations never displayed their activities so that even many Muslim scholars did not know them.

When Parmusi emerged on surface, a lot at Muslim scholars put their hope on it. Some of them joined the Sekber Golkar. Through the Golkar and Parmusi, Muslim intellectuals channelled their vertical mobility. In the 1970 the government restructured political parties and organizations on a large scale. The Islamic political parties were merged in one party. Islamic mass organizations were separated from political organization, and engaged in social activities. In 1985, the political renewal and consolidation reached its culmination with the enforcement of azas tunggal (sole basis) Pancasila. Since then, legally speaking there was no other Islamic party. In 1990 they established ICMI that was supported by the New Order government as a viable alternative to channel their socio-political activities. The vast majority of ummah initially welcomed it with respect.

The birth of ICMI (Ikatan Cendekiawan Muslim Indonesia or Association of Indonesian Muslim Intellectuals) was expected to determine Indonesian Muslim history in the years to come. To fulfil the aspiration of the ummah in colouring the decision-making process, ICMI serves as the platform to aggregate the ideas of Muslim intellectuals. ICMI is a non-political movement, although it was bound to Islamic commitment. ICMI was not intended to revive primordialism. In Azyumardi Azra's words, ICMI will become "braintrust" of the New Order government in the years to come. ${ }^{30}$

In general, there were different approaches the Muslim leaders to the modern-challenges: legal, cultural, and social transformation. Legalistic approach aimed at revamping the existing order and society under the blue-print of Islamic legal, ritual and formalistic precept. Islamic doctrine and laws to became the sole standard of reference in all practices and affairs in the society.

The cultural approach is aimed at distilling methods from Islamic teachings, which are capable of integrating non-religious sphere (secularist part) into a new totally Islamic framework of development. ${ }^{31}$ To this end, ICMI suggests that modernity must be faced through efforts to develop institutions (banking, scientific enterprises, economic, politics, etc.) in line with the Islamic teachings.

${ }^{30}$ Berita Buana, December 7, 1990.

${ }^{31}$ John Naisbitt, Megatrends Asia: The Eight Asia Megtrends that are Changing the World (London: Nicholas Brealey, 1996), pp. 103-240. 
The transformation approach aimed at seeking solutions to the problems of modernity by avoiding exclusivist attitude both towards neo-orthodox and non-Islamic aspirations. It advocated accommodative attitude and introduced disturbing questions related to the central doctrine of orthodoxy. Therefore the leading advocates of ICMI like H.M Soeharto and Prof. Dr. B.J Habibie would like to mould ICMI on the ideology of Pancasila, close to Indonesian culture, "Modern-Muslim", and high quality Muslim.

The leading Indonesian Muslim intellectuals like B.J. Habibie, ${ }^{32}$ Nurcholish Madjid, Amin Rais, Quraish Shihab, Imaduddin, Ali Yafie, Abdurrahman Wahid and others have pursued this transformative strategy, advocating non-confrontational understanding of Islam and modernity, seeking open dialogue with other groups for reaching mutual understanding of problems faced by society in general, and encouraging the ummah to work together with others in resolving such pressing questions as massive poverty, abuses of human rights, ${ }^{33}$ the stagnation of democratization, etc.

Although ICMI is not a political organization, its basic purpose and objective is political in nature. B.J. Habibie, the general chairman of ICMI, firmly rejects the notion that ICMI is a political organization, and insists that it does not belong to any political organization. It was established only to fight against ignorance and poverty among Muslims. ${ }^{34}$

In line with B.J. Habibie's statement, Soetjipto Wirosardjono and Nurcholish Madjid rejected the thinking of those activists of ICMI who exploited Islamic symbols for political purposes; including democratization and de-militarization, especially when they did not understand the meaning of religious symbol they manipulated. ${ }^{35}$ On the other side, Aswab Mahasin as a "non-active" member of ICMI has expressed his worry that ICMI has become a "pseudo-political party" and behaves like a "political machine."36 For the same reason Nurcholish Madjid and Amin Rais had withdrawn their support from

\footnotetext{
32 See, “Otokritik Tahun Keempat, Silaturrahmi ICMI," Gatra, No. 9 Tahun I, Jakarta (January 14, 1995), p. 36.

33 Douglas E. Ramage, Politics in Indonesia: Democracy, Islam and the Ideology of Tolerance (London: IB Tauris, 1995), p. 36.

${ }^{34}$ Merdeka, December 8, 1992 and Merdeka, November 30, 1992.

${ }^{35}$ Ramage, Politics in Indonesia, p. 95.

36 Ibid., p. 94.
} 
the organization in the years after its establishment, because they observed that ICMI was too political.

In the context of ICMI, Adi Sasono argued that the key issues for ICMI are democratization and an eventual reduction in the military's political role. The problem with ABRI (Angkatan Bersenjata Republik Indonesia, Indonesian military), he noted, is that it was worried about any challenge to position. ${ }^{37}$ Hence, it was understandable that ABRI expressed its displeasure over the birth of ICMI. Democratization is not the primary goal of many in ICMI, because the main objective of its activities is to empower the state in order to Islamize society and enact Islamic value based on law and regulations. Mokhtar Mas'oed, a political scientist at Gajah Mada University argues that Abdurrahman Wahid and the NU on the other hand "seeks to empower the people" and in so doing both Muslim, and non Muslim Indonesian will be empowered." 38

In the years after Soeharto came to power, the ummah felt many obstacles in political field. Moh. Kamal Hassan in his treatise on Muslim intellectual response toward modernization of the New Order in Indonesia, pointed out in 1968 that Muslims and Islamic political party leaders realized the government considered that politically strong Islam will threaten Pancasila Democracy, the new political system of the New Order, although the regime did need legitimacy from Islam in order to make the PELITA (Five-Year Development) success. ${ }^{39}$ Even according to Deliar Noer, ex-national chairman of HMI (1953-1955 period), the New Order government not merely opposed the Islamic political organizations, but also curbed their efforts which were related directly to the religious issues. For instance, the government ever prohibited the ummah to hold a congress in 1968, and monopolized the management of pilgrims to Mecca in the same year, eliminated school holidays in the month of fasting (Ramadhan) and reduced all facilities needed by the ummah in commerce. The government introduced a draft marriage bill, which was regarded offensive to Islam..$^{40}$

\footnotetext{
${ }^{37}$ Ibid., pp. 96-97.

38 Ibid., pp. 110-111.

${ }^{39}$ Hassan, Muslim Intellectual Responses to "new order" Modernization, p. 44.

${ }^{40}$ Deliar Noer, "Islam a Political Force in Indonesian," in J. J. Fox et al, (eds), Indonesia: Australia Perspectives (Canberra: Research School of Pacific Studies, ANU, 1980), pp. 642-3.
} 
In other words, it was obvious that the government needed Islam when it supported the government and gave it legitimacy. Once the government supported establishment of Parmusi, for instance, it resulted in the undermining of PNI. On the contrary, the government obstructed all activities perceived as threatening the government power; for instance, the proposal of Mohammad Hatta, the former vice President, to establish PDII (Partai Demokrasi Islam Indonesia) was not agreed by the government. Even the creation Parmusi, according to Samson, did not benefit the Muslim modern group in Indonesia. One of the weaknesses of the party was its failure to receive recognition as a legal and influential political force, namely possessing the political power in proportion to the number of its followers. ${ }^{41}$ Several repressive policies which had negative impact for future of Islam are more obvious in the 1980's. According to Vatikiotis, the government succeeded in destroying Islamic parties, with the religious politics of the New Order which emphasized harmony, whereas the Muslim community felt it was political chaos. ${ }^{42}$ The Islamic political forces had indeed declined.

In the period between 1970-1986, which, in terms of the process of the de-politization of Islam might be called the "period of exorcising", the regime began to exercise a formal way to depoliticize Islam by activating national laws obligating all political parties and mass organization to subscribe to the Pancasila as the sole foundation. While the NU decided to replace its Islamic foundation with the Pancasila at its congress in 1984 when the draft law was under discussion in the DPR, Muhammadiyah and HMI chose to wait until the draft was legislated.

\section{The Politicization of Islam and the Fall of Soeharto Regime}

Many Muslim leaders were concerned that the process of Pancasilaization would mean deislamization. ${ }^{43}$ For them, Muslims' acceptance to Pancasila as a national consensus should not be understood as a theological statement, but only as a political one. They

\footnotetext{
41 A. A. Samson, "Religious Belief and Political Action in Indonesian Islamic Modernism," in R. William Liddle (ed.), Political Participation in Modern Indonesia, Monograph series No. 19 (Yale University Southeast Asia studies), p. 116.

42 M. R. J. Vatikiotis, Indonesian Politics under Subarto: Order, Development and Pressure for Change (London: Routledge, 1993), p. 120.

${ }^{43}$ Ibid.
} 
referred to President Soeharto's statement of 1982 that Pancasila would not become a religion and the religion would not be Pancasila.

There is a group within the Muslim community responded to the political process in a more reactionary way. ${ }^{44}$ The emergence of this group, which might be labelled as fundamentalist, was a result of an internal dynamic within the Muslim community aimed at protecting Islam and Muslims from the impact of the ongoing political process. The majority of Indonesian Muslims did not support this group. This is understandable because the nature of Indonesian Islam which, following the line of Indonesian culture, is devoted to moderation, tolerance and harmony. Beside this the situational logic of politics, which has created fear and to some extent apathy, within the society would encourage Muslim cadres to initiate political change by attempting to seek justification from Islam.

The Indonesian Muslim intellectual has tried to give answers to the social problems faced by the Muslim community. The answers resulted from two coincidental factors; the real condition of the Muslim community stemming from its struggle in seeking the adequate relationship between Islam and Indonesian culture, and the emergence of a new educated Muslim generation. The majority of leaders of the new generation are dissatisfied with the ways of old generation who had been attempting to sidetrack the problems and the condition of the Muslim community.

The launching of asas tunggal Pancasila by the government initially received strong reaction from Muslim community of the country. The culmination of the reaction was a riot in Tanjung Priok, the Jakarta Harbour area in August 1984, in which hundreds of Muslim died at the hands of the Indonesian army and several prominent figures were arrested, including two members of the petition 50 group; A.M Fatwa and (Lt. Gen. Ret.) H.R. Darsono. The former was a famous Muslim preacher and the latter was a famous former commander in Chief the west Java based Siliwangi Division of the Armed Forces. This incident was followed by a series of incidents during the year 1984-1985 that threatened the stability of the governance, such as the explosion at Bank Central Asia (BCA) in Jakarta, the Borobudur Buddhist Temple in Yogyakarta, and the Marine Base in Cilandak, Jakarta. A Muslim group was accused of responsibility for the first two explosions. For

${ }^{44}$ Ibid. 
many, these incidents were not unconnected to each other, and were reactions to the regime's political engineering programmes, which showed the tendency to centralize and accumulate power.

The above issues presented a negative image of Islam to the young generation during the New Order era, and also forced their alienation from the government. To this stage, the ummab faced a dilemma. If they were close to the government, it was contrary to the real condition. If they remained away from the government, it would benefit the anti-Islam groups, particularly Christians. M. Amin Rais saw the former indication. According to that Indonesia is a centre of Christian activities for "Christianization" of the ummah through five strategic steps, namely education, mass media, economic assistance, marriage relationship and political power. 45

The condition was worse as the growth of corruption in the country under Soeharto regime had become so rampant. But it can hardly be avoided in a discussion of national level openly and transparently. While for long time, corruption was the whip with which neo-liberals would beat opponents of liberalization, now it is becoming increasingly obvious that there is a close correspondence between liberalization and the scale of corruption. This indeed is now recognized as a global problem. ${ }^{46}$ The corruption adds to the myopia of private investment decisions, since the commitments and contracts won through corruption are even more vulnerable to political instability. While the number of unemployed is more increasing and dismissal of workers in big factories occurred almost every day and it was quite vulnerable to the social unrest on large scale.

The people's frustrations reached culmination as the university students throughout the country voiced their suffering via a huge demonstration demanding of President Soeharto to step down immediately. It was on 21 May 1998, the downfall of Soeharto paved the way to Prof. B.J. Habibie as Vice President to become the third Indonesian President. Unfortunately, the downfall of Soeharto did not mark a complete break with the past. President Habibie has performed

\footnotetext{
${ }^{45}$ M. Amien Rais, "Gerakan Kristian di Asia Tenggara: Kasus Indonesia”, Working paper on seminar of Isu-isu Dakwah Kontemporer dan Cabaran Abad ke 21, in Marang, Trengganu, Malaysia, September 1994

${ }^{46}$ See "The Symposium on Corruption: Constraints," in B. Plescovic and JE. Stiglitz (eds), Annual World Bank Conference on Economic Development 1997 (The World Bank, 1998). See in particular the article by Susan-Acherman.
} 
better than feared as he has tried to institute changes (such as the election), but re remains a Soeharto appointee in his policies. The corruption of the Soeharto years has been white-washed rather than investigated. ${ }^{47}$

While politicians and academicians in Jakarta are preoccupied with political and economic reform, the concern in rural areas is much more down to earth. In the fast few weeks, demonstrations have broken out in at least 50 districts (called regencies in Indonesia) from Sumatera to Nusa Tenggara. Many of the protests are related to disputed land ownership. All fall into the category of what Indonesians call KKN (Korupsi, Kolusi, Nepotisme) ${ }^{48}$ which is fuelling public demands for a full investigation of the Soeharto family's wealth. Once Habibie noted that "they are like people who have not had oxygen for 32 years". ${ }^{49}$ In brief it can be said that the collapse of Soeharto regime is the logical consequences of his politicization of Islam that not sided its ummab in its real meaning and not for the prosperity of Indonesian people.

\section{Conclusion}

In the later political development it was found that the role of government and the ABRI was very dominant, and on the other hand, the role of political parties had been emasculated, particularly after the policy of restructuring political parties and enforcement of asas tunggal in post 1985 period. In such a condition, many Muslim intellectuals established NGOs and put their efforts in bringing about social transformation to the ummah. Figures like Abdurrahman Wahid, Nurcholish Madjid, Adi Sasono, Dawam Rahardjo, Tawang Alun and others were actively involved in these institutions and they were ready to welcome Indonesia's reform era as the Soeharto goverment was toppled down in 1998.]

\footnotetext{
47 The Times of India, May 10, 1999.

${ }^{48} \mathrm{KKN}$ is the local abbreviation for corruption, collusion and nepotism.

49 "Politics \& Policy," Far Eastern Economic Review, June 25 (1998), p. 21.
} 


\section{References}

\section{Books and Articles}

Douglas, E. Ramage. Politics in Indonesia: Democracy, Islam and the Ideology of Tolerance. London and New York: Routledge, 1995.

Graha Insan Cita. Pidato Ketua Umum PB HMI pada Dies Natalis yang ke 51. Depok, February 05, 1998.

Fox, JJ (ed.). Indonesia: Australia Perspective. Canberra Research School of Pacific Studies, ANU, 1980.

Hasan, Muhammad Kamal. Muslim Intellectual Response to "New Order" Modernization in Indonesia. Kuala Lumpur, 1980.

John, Naisbitt. Megatrends Asia: The Eight Asia Megatrends that are Changing the World. London: Nicholas Brealey, 1996.

Liddle, R. William (ed.). Political Participation in Modern Indonesia. Monograph Series, No. 19. Yale University Southeast Asia Studies. 1973.

Liddle, R. William. "Evolution from Above, National Development and Local Leadership in Indonesia." Journal of Asian Studies, No. 32, 1973.

Madjid, Nurcholish. Keharusan Pembaharuan Pemikiran Islam dan Masalah Integrasi Ummat. Jakarta: Islamic Research Centre, 1970.

Mintaredja, HMS. Islam, Politics and State. Jakarta: Siliwangi, 1972.

"Politics and Policy." Far Eastern Economic Review, June 25, 1998.

Plescovic \& Stightz (eds). "The Symposium on Corruption Constraints." in Annual Word Band Conference on Economic Development.

Rahmat, Jalaluddin. Islam Aktual: Refleksi Sosial Seorang Cendekiawan Muslim. Bandung: Mizan, 1996).

Rais, M. Amin. “Gerakan Kristian di Asia: Kasus Indonesia.” Working paper on Seminar of Isu-isu Dakwah Kontemporer dan Cabaran Abad ke 21, in Matang, Trengganu, Malaysia, September 1994. 
Masykur Hakim

Sjadjali, Munawir. Muslim's Indonesia Are Better in the Absence of Muslim Parties. Jakarta: Department of Religious Affairs, 1992.

Tanja, Victor. HMI, Sejarah dan Kedudukannya di Tengah Gerakan-Gerakan Muslim Pembaruan di Indonesia. Jakarta: Sinar Pustaka, 1991).

Yusuf, HM (ed.). 50 Tabun HMI Mengabdi Republik. Jakarta: LASPI, 1997).

\section{Newspapers}

Berita Buana, December 07, 1990

Merdeka, December 08, 1992.

The Time of India, May 10, 1999. 